\title{
Public attitudes toward nuclear power plants in Turkey
}

\section{Türkiye'de Nükleer Güç Santrallerine karşı halkın tutumları}

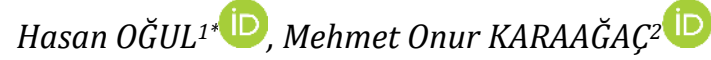 \\ 1Department of Nuclear Engineering, Faculty of Engineering and Architecture, Sinop University, Sinop, Turkey. \\ hogul@sinop.edu.tr \\ ${ }^{2}$ Department of Energy Systems Engineering, Faculty of Engineering and Architecture, Sinop University, Sinop, Turkey. \\ okaraagac@sinop.edu.tr
}

Received/Geliş Tarihi: 06.10.2018, Accepted/Kabul Tarihi: 21.12.2018

doi: $10.5505 /$ pajes.2018.97415

* Corresponding author/Yazıșılan Yazar Research Article /Arastırma Makalesi

\begin{abstract}
Due to the increasing energy need, countries are required to optimize their usage of energy sources for sustaining developments. One of the options to meet the sustainable energy is the use of nuclear power plants (NPPs). However, building and using NPPs represent a great challenge to policy makers of the countries: acceptance of this technology by the citizens. Turkey is one of the countries decided to establish NPPs and adjust their policy in this regard. The country's first NPP is already under construction in Mersin, and the second will be established in Sinop. A survey to evaluate public acceptance of NPPs was given to 838 individuals from different cities of Turkey. The participants were interviewed face-to-face between January and March 2018. The endorsement and opposition rates were determined as $42.3 \%$ and $31.1 \%$, respectively. The margin of error at 95\% CL was found to be $\pm 3.3 \%$. Measuring the participants' knowledge of NPPs was also aimed. It has been asked to respondents express if they have basic knowledge of NPPs. 72\% of the participants stated that they know the basics of NPPS. To extract the actual rate, three simple questions regarding NPPS have been asked, and only 24.9\% of all participants answered 2 or 3 questions correctly. The results were further compared with previous surveys for Turkey and other countries.
\end{abstract}

Keywords: Public acceptance, Sinop NPP, nuclear energy policy in Turkey

\section{Introduction}

Energy need of countries is continuously increasing with increases of population and aspirations on technology and developments. For sustainable energy technologies and assessments, the countries require more energy production using the available limited resources. In this regard, nuclear energy is an alternative and sustainable energy source particularly preferred by developing and developed countries. Despite its various advantages [1] nuclear power carries crucial doubts and rising costs [2],[3], and it is a fact that public opinion on energy sources are crucial to determine energy policy of countries. This fact has been proved in the past: Switzerland voted to phase out nuclear power in a 2017 referendum, and the votes paved the way for them not to have any plans to build more nuclear power plants (NPPs). Although there are many key parameters effective on public attitude to nuclear energy, majority of the studies carried out in different countries regarding public opinion revealed that the oppositions are mainly rising due to the risk of nuclear accidents [4]-[11].
Öz

Artan enerji ihtiyacından dolayı ülkelerin sahip oldukları enerji kaynaklarını sürdürülebilir gelişme için en iyi şekilde kullanmak zorundadırlar. Sürdürülebilir enerjiyi karşılamak için seçeneklerinden bir tanesi de nükleer güç santrallerin (NGS) kullanılmasıdır. Ancak, NGS'lerin inşa edilmesi ve faaliyete geçirilmesi ülkelerin politika yapıcılarına cözülmesi gereken büyük bir sorunu sunmaktadır: bu teknolojinin halk tarafindan kabul edilebilirliği. Türkiye, NGS'leri kurmayı ve politikalarını bu yönde değiştirmeye karar veren ülkelerden bir tanesidir. Ülkenin ilk NGS'si halihazırda Mersin'de yapım aşamasındadır ve ikincisi ise Sinop ilinde kurulacaktır. Türkiye'nin farklı şehirlerinden 838 kişiye NGS'lerin halk tarafindan kabul edilirliğini değerlendirmek için bir anket yapılmıştır. Katılımcılara anketler 2018 Ocak-Mart ayları arasında yüz-yüze görüsme esnasında yapılmıștır. NGS'leri destekleme ve karșı olma oranları sırasıly $42.3 \%$ ve $31.1 \%$ olarak belirlenmistir. \%95 güven seviyesindeki hata payı $\pm \% 3.3$ olarak bulunmuştur. Katılımcıların NGS konusundaki bilgilerinin ölçülmesi de bu anket amaçları arasındadır. Anket katılımcılarından, NGS'lere ilișkin temel bilgiye sahip olup olmadıklarını ifade etmeleri istenmiştir. Katılımcıların 72\%'si NGS'lerin temel prensiplerini bildiğini belirtmiştir. Buradaki gerçek değerin ortaya çıkarılması için, NGS'lere ilişkin üç adet basit soru sorulmuştur ve tüm katılımcıların sadece $24.9 \%$ 'u 2 ya da 3 soruyu doğru bir șekilde cevaplamıștır. Ayrıca, elde edilen sonuçlar daha önceki Türkiye ve diğer ülkeler için yapılmış çalıșmalarla karşılaştırılmıştır.

Anahtar kelimeler: Toplumsal kabul, Sinop NGS, Türkiye'de nükleer enerji politikası

Germany can be presented as a good example of this fact. Due to the Japan's Fukushima nuclear disaster, the opposition to and doubts on NPPs in Germany were highly increased as it was in all over world. Just 3 months after the Fukushima catastrophe, Chancellor Angela Merkel's government declared that all NPPs in Germany would be shut down by 2022. Another example could be Italy to highlight the impact of nuclear accidents on public attitudes. Although Italian government was strongly supporting re-establishing nuclear power after the Fukushima accident, the country had to completely abandon it as a result of a public referendum. On the other hand, some countries, such as Czech Republic and Turkey, plan to adjust their energy programs including nuclear energy in order to satisfy their energy need and security by reducing the usage of imported fossil energy sources, regardless accident risk and other drawbacks of NPPs. Turkey is one of the countries that use imported fossil energy sources and has faced the reality that it cannot be indefinitely on combustion of fossil fuels for sustainable energy. The policy-makers of the country have been making investments on renewable energy sources and having plans for establishing nuclear power plants since early 1970 . 
Many attempts to build several NPPs in Turkey failed mainly due to economic circumstances of the country. Therefore, to ensure effective and timely investment in nuclear energy, the governments have to mobilize the extensive funds available. Finally, in 2009, Russia and Turkey had an agreement to establish a NPP at Akkuyu in Mersin, Turkey. The construction of Akkuyu NPP has begun in April 2018, and it is expected to start generating electricity by 2023 . The Sinop NPP is planned to be second nuclear power plant in Turkey, located at Sinop in northern Turkey. Both NPP aims to reduce the dependence on imported energy sources and meet the sustainable energy. Besides the delays due to the financial conditions, there are many studies reporting health effects, social and psychological consequences of Chernobyl accident for Turkey [12]-[15]. Therefore, the government has to deal with the nuclear disaster stress on public. The Turkish authorities are aware that NPPs will be a key feature to reach the aim of economic and industrial developments and Turkish Ministry of Energy and Natural Resources [16] reported that the need on electricity for the targeted economic and industrial developments by 2023 will not be satisfied even if whole solar, wind, hydroelectric, biomass and geothermal potential of Turkey are utilized.

As expressed and well discussed in Reference [17], there are two faces of nuclear energy, the face of immense promise and the face of peril, and, the public acceptance is dependent on which face comes to the forefront. Turkish government has already taken many steps to overcome the high rate of opposition to nuclear power plants. The nuclear energy policy of the country started in mid 1950s: Turkish Atomic Agency was established in 1956. Meanwhile, the government decided to open nuclear energy education programs at public colleges to promote the nuclear energy and have qualified personnel in the field. Department of Nuclear Engineering at Hacettepe University has begun teaching activities in 1977. The second and third nuclear energy programs have started at Sinop University in 2015 and Sivas Cumhuriyet University in 2017, respectively. In addition, starting from 2015, the government has been sending Turkish students to study nuclear energy abroad and gain NPP experience in Russia. Even, some of the nuclear engineers sent to Russia have already turned back to the country in December 2017 by completing their studies successfully. All these efforts are well advertised by government in press and the government is trying to convey the information to the public as much as possible. In addition, in 2017, right before starting the construction of Akkuyu NPP, UNESCO-awarded scientist Prof. Bilge Demirkoz and Nobel laureate Prof. Aziz Sancar, Turkish scientist stars, starred in a public ad to promote Turkey's first nuclear power plant, Akkuyu. Also, the government agencies and the nuclear energy companies in Turkey are visiting Turkish universities to give public lectures and opening stands in the city centers for briefings. Based on our literature search, there are only two comprehensive studies regarding public opinions to the NPPs in Turkey. The first one [4] was conducted in 2007, and the second survey [5] was made between June 2014 and June 2015. Both studies indicated that opposition to nuclear energy was strong. The rates of opposition to NPPs were found $62.5 \%$ and $70.2 \%$ for 2007 and 2014 surveys, respectively. In addition to the comprehensive studies, there are some studies deserved to be mentioned here. Those were conducted by Greenpeace [18], BBC [19] and KONDA [20] in 2011, 2011 and 2018, respectively. The opposition rates reported by Greenpeace (56.4\%), BBC (41\%) and KONDA (68.2\%) are significantly higher than our findings.

In this study, the public's perception of nuclear energy will be updated based on the survey performed in the first quarter of 2018 and the results are compared with previous studies. Our study is the first study after Turkish government's intense efforts to promote nuclear energy and indicates impacts of all efforts. It reflects a clear difference between 2007 and 2018 survey results. This difference could be improved by highlighting the advances from old generation to new generation nuclear power plants such as crucial advantages in economics, reliability and safety, and sustainability.

Since public acceptance depends on important social indicators such as age, fear, education level, perception and knowledge, the opinions and knowledge of respondents were further analyzed and discussed using basic questions regarding NPPs. The rates of that citizens find nuclear energy risky are determined based on three different age groups and three different education levels. These rates are compared with other 19 countries. Since public investment and management have been dominating the development in Turkish energy, the public acceptance and attitude to the energy sources are vital.

\section{Materials and methods}

Researchers have suggested various methodologies to evaluate the public attitude to nuclear energy, some can be found in Refs. [21]-[24] However, big data analysis and online survey methods are not good options for Turkey since the internet usage is only at $42 \%$ level, and most of the users are located in the west of the country. Since we are aiming to reach respondents from each side of the country, we chose to use face-to-face method despite the fact that this methodology requires significant time to process.

The survey aims to indicate the knowledge and thoughts of Turkish people about nuclear power plants. 838 people above 15 years of age and from different education levels and different cities of Turkey were interviewed face-to-face between January 2018 and March 2018. 513 of the respondents were male while 325 of them were female. Participants from Sinop, Antalya, Bingol, Bilecik, Izmir, Manisa, Mardin, and Samsun were randomly selected. The selection of these cities is motivated to have inputs to the study from all regions of the country. Besides, Sinop will be home of the second NPP constructed in Turkey. In addition, Samsun has a great potential of hydroelectric power, Izmir and Manisa have the high proportion of renewable energy sources and geothermal power plants, and Antalya is the city that receives the maximum solar radiation in Turkey. Also, Antalya is considered as the center of tourism, which motivates one of the survey questions. Table 1 gives the demographic information about the respondents.

In the survey, the questions were prepared to measure participants' opinions and knowledge. Answers to questions were divided into three categories (Yes, No, Undecided). First, we tried to understand the participants' thoughts on NPPs. The questions on Table 2 were asked to understand what they are thinking of. 
Table 1: Demographic information about respondents.

\begin{tabular}{|c|c|c|c|}
\hline & & Number of Respondents & $\%$ \\
\hline \multirow{3}{*}{ Gender } & Female & 325 & 38.8 \\
\hline & Male & 513 & 61.2 \\
\hline & $15-25$ & 387 & 46.2 \\
\hline \multirow[t]{3}{*}{ Age } & $26-44$ & 296 & 35.3 \\
\hline & $45+$ & 155 & 18.5 \\
\hline & High school & 463 & 55.2 \\
\hline \multirow[t]{6}{*}{ Education } & College & 338 & 40.3 \\
\hline & Graduate school & 37 & 4.5 \\
\hline & Sinop & 116 & 13.8 \\
\hline & Antalya & 127 & 15.1 \\
\hline & Bingol & 77 & 9.2 \\
\hline & Bilecik & 108 & 12.9 \\
\hline \multirow[t]{4}{*}{ Residence } & Izmir & 100 & 11.9 \\
\hline & Manisa & 99 & 11.8 \\
\hline & Mardin & 104 & 12.4 \\
\hline & Samsun & 107 & 12.8 \\
\hline
\end{tabular}

Table 2: Questionnaire sheet to determine the participants' opinions.

Yes No Undecided

Q1: Do you support NPPs in Turkey?

Q2: Should Turkey have own nuclear weapon?

Q3: Do you think NPPs are risky?

Q4: Do you think Turkey has enough qualified personnel to operate one or more than one NPPs?

Q5: Do you concern about a NPP explosion?

Q6: Do you have negative thoughts about NPPs due to the accidents happened in the past?

Q7: Would you visit Sinop NPP to understand how it works if there were public open days?

Q8: Do you think NPPs affect tourism negatively?

Public acceptance of nuclear energy can be defined as willingness to have NPPs or nuclear energy technologies; therefore, it is better to determine the endorsement rates of NPPs and nuclear weapons, separately.

To allow for an international perspective, some of the questions in the conducted survey were taken from a publication regarding public acceptance of nuclear energy [25]. Their faceto-face choice matches to our methodology. The publication includes results from Argentina, Australia, Cameroon, Canada, China, France, Germany, Hungary, India, Indonesia, Japan, Jordan, South Korea, Mexico, Morocco, Russia, Saudi Arabia, UK, and USA. The study is missing Turkey, and the authors are asking respondents to express how much they know the nuclear energy to determine the participant's knowledge. An important feature of this survey is that it is not only asking whether the participants know nuclear energy but also asking some basic questions to measure the real knowledge of participants. The question in the survey sheet, "Q9: Do you think you have basic knowledge on nuclear power plants?", was first directed to the respondents. Then, to evaluate how many of the participants really know the basics of the NPPs, the questions on Table 3 were given to the participants. If the respondent answers 2 or more questions correctly, we categorized the participant under "has basic knowledge". The remaining participants were marked, as "does not have basic knowledge". The details can be found in the results section. Previous studies were also limited to consideration of nuclear energy in peaceful methods. In our survey, we also asked if they support that Turkey should have own nuclear weapon. The outcomes of the question can be compared with supporters of NPPs and may draw a complete shape of nuclear energy public consideration. The outcomes of this survey and showing the impact of Turkey's efforts to promote nuclear energy can help governments to adjust their policies.

\section{Results and discussions}

Previous nuclear energy surveys [9],[10] indicated that there are different parameters affecting peoples' opinions to nuclear energy. Those can be age, education level, gender and the distance between where the respondent lives and the location of NPP. All these parameters were taken into consideration during the analyses of survey. As mentioned earlier, to provide an international perspective, some questions used in the study were taken from a recent publication [25], such as the question "Do you think NPPs are risky?". We found that $61.2 \%$ of respondents thinks nuclear energy as "risky". Based on the results, Figure 1 shows the number of participants who found it risky or not for different age groups and education levels. The participants with "Undecided" choice were excluded on these histograms. For the age group analysis, it could be safely stated that people within the age range of 15 and 25 have the maximum rate of thinking nuclear power plants risky while this rate is the lowest for the middle age group (26-44). On the other hand, the rate of people considering NPPs risky decreases with increase of education level. The comparison of these results with the reference [25] is given in Table 4. It should be certainly noted here that the compared results are from a paper published in 2014 while our results belong to 2018 . 

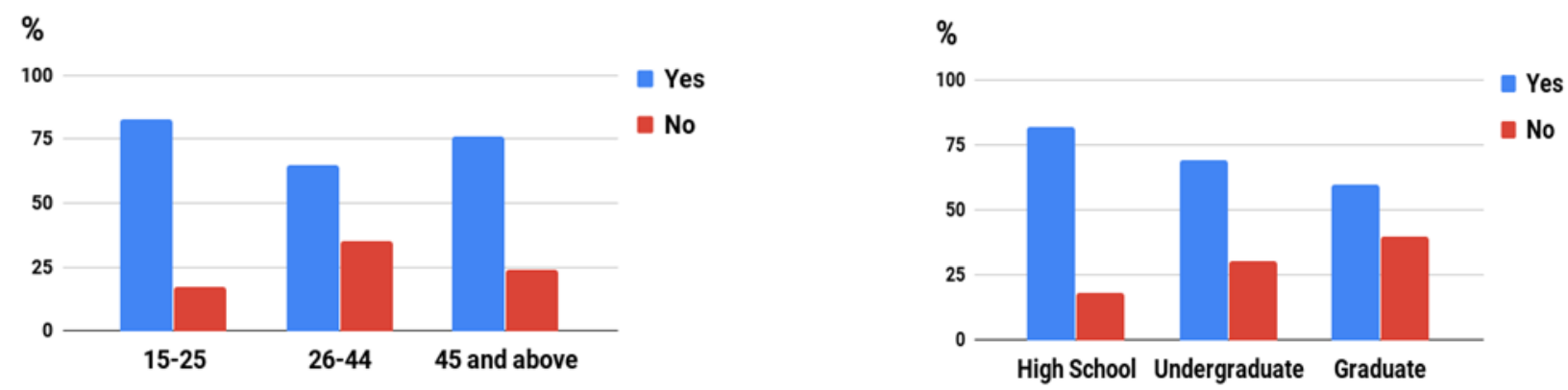

Figure 1: Age vs. risky (left) and education vs. risky (right) diagrams.

Table 3: Questionnaire sheet to determine the participants' knowledge.

Q10: Which power plant generates more electricity when equal amount of fuel is used?

Hydroelectric Power Plant Thermal Power Plant $\quad$ Nuclear Power Plant

Q11: What is the smoke coming out from the towers of nuclear plant?

Radiation Water vapor Carbon dioxide

Q12: An amount of water used for cooling is discharged back into the water source. Does the discharged water have any radiation waste or fission product?
Yes
No
No Idea

Table 4: Descriptive statistics. The results of Argentina (ARG), Australia (AUS), Cameroon (CMR), Canada (CAN), China (CHN), France (FRA), Germany (GER), Hungary (HUN), India (IND), Indonesia (IDN), Japan (JPN), Jordan (JOR), South Korea (KOR), Mexico (MEX), Morocco (MAR), Russia (RUS), Saudi Arabia (SAU), the UK (GBR), and the US (USA) are taken from a publication [22] in 2014.

\begin{tabular}{|c|c|c|c|c|c|c|c|}
\hline & \multirow[t]{2}{*}{ Respondents } & \multicolumn{2}{|c|}{ Acceptance } & \multicolumn{2}{|c|}{ Knowledge } & \multicolumn{2}{|c|}{ Risk } \\
\hline & & Endorse & Oppose & Yes & No & Risky & not risky \\
\hline ARG & 1000 & 13.9 & 22.9 & 21.6 & 52.0 & 51.2 & 19.3 \\
\hline AUS & 1020 & 35.2 & 22.9 & 18.0 & 51.6 & 53.9 & 36.6 \\
\hline CMR & 1900 & 21.5 & 27.6 & 16.9 & 44.6 & 42.2 & 25.5 \\
\hline CAN & 1012 & 34.8 & 20.9 & 13.1 & 62.6 & 50.7 & 35.3 \\
\hline $\mathrm{CHN}$ & 1800 & 61.2 & 7.4 & 52.6 & 18.3 & 50.1 & 39.3 \\
\hline FRA & 1002 & 24.9 & 16.3 & 9.7 & 64.3 & 57.4 & 32.1 \\
\hline GER & 1002 & 23.8 & 26.6 & 20.5 & 54.9 & 59.3 & 33.5 \\
\hline HUN & 1008 & 19.3 & 19.1 & 30.0 & 34.9 & 49.7 & 34.5 \\
\hline IND & 1000 & 37.3 & 19.6 & 33.6 & 24.0 & 40.7 & 32.0 \\
\hline IDN & 1000 & 33.0 & 27.6 & 29.1 & 27.4 & 61.9 & 23.4 \\
\hline JPN & 1003 & 20.7 & 14.6 & 52.0 & 13.0 & 79.5 & 15.6 \\
\hline JOR & 800 & 36.5 & 39.5 & 32.9 & 42.1 & 52.3 & 38.1 \\
\hline KOR & 1000 & 51.1 & 12.0 & 63.6 & 7.6 & 56.9 & 37.4 \\
\hline MEX & 1000 & 33.0 & 23.0 & 34.7 & 20.5 & 59.5 & 25.0 \\
\hline MAR & 1038 & 10.0 & 38.0 & 12.5 & 1.2 & 42.8 & 7.0 \\
\hline RUS & 1003 & 21.0 & 19.9 & 17.4 & 47.3 & 63.5 & 21.1 \\
\hline SAU & 1200 & 16.1 & 35.9 & 48.6 & 20.1 & 42.7 & 30.8 \\
\hline GBR & 1011 & 33.0 & 22.2 & 13.2 & 58.7 & 54.7 & 35.5 \\
\hline USA & 1004 & 45.8 & 13.7 & 23.5 & 50.8 & 56.3 & 28.7 \\
\hline Total & 20803 & 30.7 & 22.2 & 29.2 & 36.0 & 53.2 & 29.1 \\
\hline Turkey & 838 & 42.3 & 31.1 & 72 & 24.2 & 61.2 & 19.3 \\
\hline
\end{tabular}

The rates of the question "Do you support NPPs in Turkey?" were found to be $42.3 \%, 31.1 \%$, and $26.6 \%$ for "Yes", "No", and "Undecided", respectively. The margin of error with a confidence level of $95 \%$ was found to be $\pm 3.3 \%$. To the best of our knowledge, endorsement of nuclear energy in Turkey was found at highest level up to date. The reason is clear that the government efforts to promote the NPPs work well; however, undecided people are also at high rate. As it is obtained from the face-to-face interviews, most of the participants consider nuclear energy is just another energy option; therefore, the rate of "Undecided" might be at high level. To increase the endorsement and decrease the undecided rate, the policy 
makers should let residents to know that nuclear energy is not just another energy option; it is also a clean energy source and will be beneficial to the environment. Most of the participants in Turkey are not aware of the fact that nuclear energy is a clean energy source. Comparison to other countries from Table 4 explicitly shows that the endorsement rate is higher than or close to most of the countries having NPP technology at that time, such as USA, France, Germany, Japan, Russia, India, and the UK. Table 5 gives the rates of opposing and endorsing NPPs for women and men, separately. Men are found to be more likely to support while women tend to strongly oppose. Another valuable remark here is that $1 / 3$ of the women were "Undecided".

Dear in Ref. [26] suggests that the residents living nearer to unwanted facilities tend to more oppose comparing to those living further away. Therefore, besides the gender study, impact of the distance between the location of NPPs and the participant was investigated. The considered cities were chosen different regions of Turkey with different distances to Sinop NPP. The opposition rate was found to be close to each other for the selected cities (except Sinop), which means that participants did not mind the location of NPP. Although Sinop is the city that will be home of the second NPP in Turkey, the endorsement rate was found to be $52 \%$, the highest value among the selected cities. The opposing and undecided people are $31.0 \%$ and $26.6 \%$ of the respondents from Sinop, respectively. So, we reported the opposite of the hypothesis assumed in Ref. [26].

In addition to citizens' point of view to NPPs, their desire to owning nuclear weapon was evaluated since the nuclear energy can be used for military purposes as well as peaceful usages. The rates of $45 \%, 43 \%$, and $12 \%$ were determined for "Yes", "No", and "Undecided". Endorsement of nuclear weapon is slightly higher than the endorsement of NPPs (42.3\%) while opposition to nuclear weapons was found to be much greater than opposition to NPPs (31.1\%). The sharp increase on the opposition rate might support the statement "People prefer peaceful uses of nuclear energy". Table 6 presents the results for the questions 4, 5, 6, 7, and 8. Majority of the participants think that the country does not have enough qualified personnel to operate one or more than one NPP although the press often declare that the government sent many students to abroad to study nuclear engineering [27]-[29] and there are three department of nuclear engineering at public universities. Even, right before this survey was conducted, it was reported in December 2017 that the first group of the students graduated in Russia and was turning back to the country [29]. Questions 5 and 6 indicate that opposition to nuclear energy mainly relates to NPP explosion anxiety and the nuclear accidents happened in the past, which is a common outcome of all previous studies in the area. Questions 7 and 8 highlight the respondents' opinions to the impact of NPPs on the tourism. People are more likely not to visit an NPP and majority of participants think that NPPs have negative impact on tourism.

The second part of the survey is to examine whether people know the basics of NPPs or not. Interestingly, $72 \%$ of the participants expressed that they have basic knowledge of NPPs. These numbers can be also compared with other countries listed in Table 4. The highest rate of knowledge was claimed in Turkey. Turkish citizens were very confident on their knowledge. Therefore, we had to derive the actual rate for this question. Three additional questions given in Table 3 were used to measure the participants' actual knowledge level. It is found that only $24.9 \%$ of the respondents answered 2 or 3 questions correctly. The numbers are illustrated in Figure 2.

\section{Conclusion}

After 2015, the government made many efforts to promote the nuclear energy in Turkey. Those can be listed as sending students to abroad to study nuclear energy, advertising nuclear energy with Turkish scientist stars, starting new nuclear engineering programs at public universities, and funding local companies to collaborate with international nuclear energy companies. Especially, when Turkish scientist stars, UNESCOawarded scientist Prof. Bilge Demirkoz and Nobel laureate Prof. Aziz Sancar, starred in ads, everyone was talking about nuclear energy. It could be safely stated that the policy followed by Turkish government is successful. In this work, the rate of opposition against NPPs in Turkey was found to be $31.1 \%$ while the endorsement was determined as $42.3 \%$. The opposition and endorsement rates for Turkish people were previously reported by Ertor-Akyazi [4] et al., Ozcan [5], Greenpeace [18], BBC [19] and KONDA [20]. KONDA, a research company in Turkey, conducted a public survey about climate change in March 2018. In KONDA research, the opposition rate to nuclear power plant was found to be $68.2 \%$, which is significantly higher than our findings. However, the question asked to determine this rate was not a direct question for nuclear energy preferences: "Which of the two power plants you oppose most?". Therefore, we exclude the results of KONDA from the comparison table. Table 7 compares our results with the previous reports.
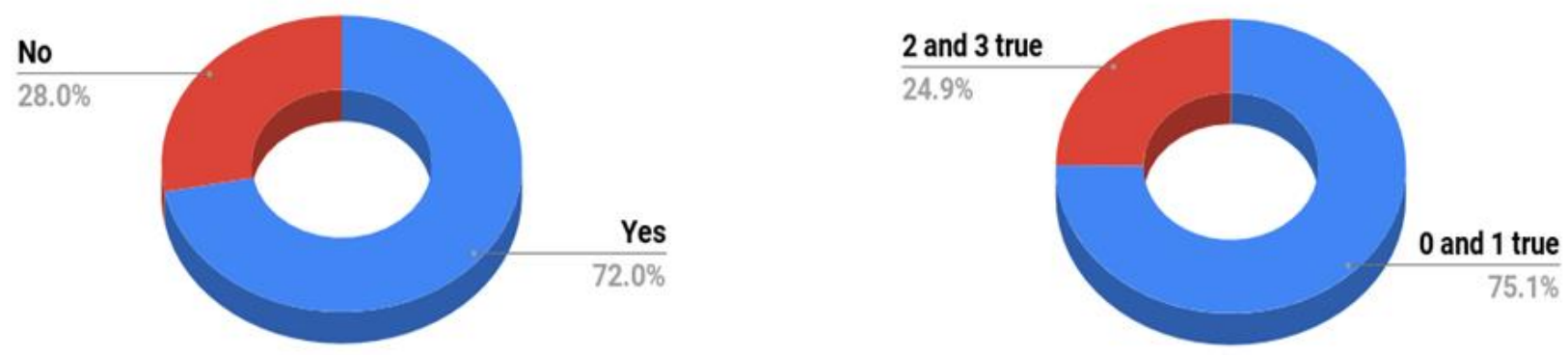

Figure 2: Age vs. risky (left) and education vs. risky (right) diagrams. 
Table 5: Gender vs. opposition to and endorsement of NPPs in Turkey.

\begin{tabular}{cccccc}
\hline & Women & \multicolumn{3}{c}{ Men } \\
\hline Endorsement & Opposition & Undecided & Endorsement & Opposition & Undecided \\
$28.3 \%$ & $37.2 \%$ & $34.5 \%$ & $49.7 \%$ & $27.1 \%$ & $23.2 \%$ \\
\hline
\end{tabular}

Table 6: Rates of questions 4, 5, 6, 7 and 8.

\begin{tabular}{|c|c|c|c|}
\hline & Yes & No & Undecided \\
\hline Q4: Do you think Turkey has enough qualified personnel to operate one or more than one NPP? & $26.7 \%$ & $50.5 \%$ & $22.8 \%$ \\
\hline Q5: Do you concern about a NPP explosion? & $69.5 \%$ & $21.9 \%$ & $8.6 \%$ \\
\hline Q6: Do you have negative thoughts about NPPs due to the accidents happened in the past? & $69.7 \%$ & $23.0 \%$ & $7.3 \%$ \\
\hline Q7: Would you visit Sinop NPP to understand how it works if there were public open days? & $37.1 \%$ & $51.1 \%$ & $11.8 \%$ \\
\hline Q8: Do you think NPPs affect tourism negatively? & $51.7 \%$ & $30.2 \%$ & $18.1 \%$ \\
\hline
\end{tabular}

Table 7: Comparison of 2018 results with previous reports.

\begin{tabular}{ccccc}
\hline & Endorsement & Opposition & Undecided & Year \\
\hline Our study & $42.3 \%$ & $31.1 \%$ & $26.6 \%$ & 2018 \\
M. Ozcan & $18.9 \%$ & $70.2 \%$ & $10.9 \%$ & $2014-2015$ \\
Greenpeace & $31.8 \%$ & $56.4 \%$ & $11.0 \%$ & 2011 \\
BBC & - & $41 \%$ & - & 2011 \\
P. Ertor-Akyazi et al. & $7.2 \%$ & $62.5 \%$ & $30.3 \%$ & 2007 \\
\hline
\end{tabular}

According to the reported numbers, opposition to nuclear energy reaches to highest level in 2014 and 2015, and our study reveals that the endorsement rate of nuclear energy is currently higher than the rate of opposition. Also, it should be noted here that the opposition rate in 2018 was found to be almost half of the opposition rate in 2007. It should be also highlighted here that the endorsement rate of NPPs in Turkey is found to be higher than or equal to many countries that have nuclear energy, such as USA, France, Germany, Japan, Russia, India, and the UK. The policy followed by Turkey could be useful for other countries.

In the presented study, it is also found that majority of participants think that they know what nuclear power plant is although the obtained results indicate opposite. The selected questions to measure the respondents' knowledge are very basic questions of NPPs, and they revealed that only $24.9 \%$ of the participants answered 2 or 3 questions correctly. Although it is founded that the policy followed by the Turkish government is effective, the residents are lack of nuclear energy knowledge. The majority of the respondents consider the nuclear energy as an alternative energy source to satisfy the energy need for sustaining developments since all efforts made by the government convey this to residents. The policy makers of the country need to tell people that the nuclear energy is not just another energy option, and it is also crucial for the environment. This could reinforce the endorsement rate and prepare a good future of nuclear energy. This rate should let authorities criticize themselves and they should reach to public not only to tell that nuclear energy is a need for economic and industrial developments but also to give them the basics of NPPs and its impact to the environment regardless of whether they support it or not.

\section{References}

[1] Cravens G. Power to Save the World: The Truth About Nuclear Energy, 1 1 ${ }^{\text {nd }}$ ed. New York, USA, Knopf 2007.

[2] Cooper M. "Policy challenges of nuclear reactor construction: cost escalation and crowding out alternatives". http://www.ises.org.il/assets/files/News /20100909_cooperStudy.pdf, (01.10.2018).
[3] Cernoch F, Zapletalova V. "Hinkley Point C: a new chance for nuclear power plant construction in central Europe?". Energy Policy, 83, 165-168, 2015.

[4] Ertor-Akyazi P, Adaman F, Ozkaynak B, Zenginobuz U. "Citizens' preferences on nuclear and renewable energy sources: Evidence from Turkey". Energy Policy, 47, 309-320, 2012

[5] Ozcan M. "Citizens' opinions about nuclear power plants". $9^{\text {th }}$ International Conference on Electrical and Electronics Engineering, Bursa, Turkey 26-28 November, 2015.

[6] Yoo $\mathrm{H}$ and Lee J. "Results of Nuclear Security Culture on Personnel at Nuclear Power Plants". Annals of Nuclear Energy, 85, 398-402, 2015.

[7] Zhang Q, Mclellan B C, Tezuka T, Ishihara K N. "Economic and environmental analysis of power generation expansion in Japan considering Fukishima nuclear accident using a multi-objective optimization model". Energy, 44 (1), 986-995, 2012.

[8] Kessides I N. "The future of the nuclear industry reconsidered: Risks, uncertainties and continued promise". Energy Policy, 48, 185-208, 2012.

[9] Ansolabehere S, Konisky D M. "Public attitudes toward construction of new power plants". Public Opinion Quarterly, 73 (3), 566-577, 2009.

[10] Webber D J. "Is nuclear power just another environmental issue? An analysis of California voters". Environment and Behavior, 14 (1), 72-83, 1982.

[11] Bisconti AS. "Changing public attitudes toward nuclear energy". Progress in Nuclear Energy, 102, 103-113, 2018.

[12] Ozyar E. "Effects of Chernobyl Accident on Turkey." Environmental Protection Against Radioactive Pollution, 33, 85-88, 2003.

[13] Akcay B. "The case of nuclear energy in Turkey: From chernobyl to Akkuyu Nuclear power plant". Energy Sources, Part B: Economics, Planning, and Policy, 4 (4), 347-355, 2009.

[14] Acar H, Çakabay B, Bayrak F, Evrenkaya T. "Effects of the Chernobyl disaster on thyroid cancer incidence in Turkey after 22 Years". ISRN Surgery, 10, 1-3, 2011. 
[15] Gökmen I, Birgül O, Kence A, Gökmen A. "Chernobyl radioactivity in Turkish tea and its possible health consequences". Journal of Radioanalytical and Nuclear Chemistry, 198(2), 487-497, 1995.

[16] T.C. Enerji ve Tabi Kaynaklar Bakanlı̆̆ı. "Nükleer Santraller ve ülkemizde kurulacak nükleer santrale ilişkin bilgiler (Nuclear Power plants and detailed information to the nuclear plant to be installed in our country)". Ankara, Turkey, 1, 2010.

[17] Roh S. "Big data analysis of public acceptance of nuclear power in Korea". Nuclear Engineering and Technology, 49, 850-854, 2017.

[18] Greenpeace. "Türkiye'nin \%64'ü Nükleere Hayır Diyor" http://www.greenpeace.org/turkey/tr/ews/turkiyeninyuzde-64u-nukleere-hayir-diyor 290411 (11.07.2018).

[19] BBC "Nuclearenergy" http://www.globescan.com/images/images/pressreleas es/bbc2011_nuclear_energy/bbc2011_energy.pdf (11.07.2018).

[20] KONDA.

"ClimateSurvey". https://www.iklimhaber.org/climatesurvey2018 (11.12.2018).

[21] Frantal B, Maly J. “Close or renew? Factors affecting local community support for rebuilding nuclear power plants in the czech republic". Energy Policy, 104, 134-143, 2017.

[22] Bird D K, Haynes K, Honert R, McAneney J, Poortinga W. "Nuclear power in Australia: A comparative analysis of public opinion regarding climate change and the Fukushima disaster". Energy Policy, 65, 644-653, 2014.
[23] Yuan X, Zuo J, Ma R, Wang Y. "How would social acceptance affect nuclear power development? A study from China". Journal of Cleaner Production, 163, 179-186, 2017.

[24] Kim Y, Kim W, Kim M. "An international comparative analysis of public acceptance of nuclear energy". Energy Policy, 66, 475-483, 2014.

[25] Dear M. "Understanding and overcoming the NIMBY syndrome". Journal of the American Planning Association, 58, 288-300, 1992.

[26] Hurriyet. "Nükleer Eğitim için Rusya'ya 600 Öğrenci Gönderilecek 600 Students Will Be Sent to Russia for Education in Nuclear Engineering". http://www.hurriyet.com.tr/ekonomi/nukleer-egitimicin-rusyaya-600-ogrenci-gonderilecek-20537908 (12.05.2012).

[27] Trend News Agency. "Turkey to Send 100 Students to Russia for Nuclear Education". https://en.trend.az/world/turkey/2246470.html (26.02.014).

[28] Hurriyet Daily News. "Turkey to Send 80 Students to Russia for Nuclear Education". http://www.hurriyetdailynews.com/turkey-to-send-80students-to-russia-for-nuclear-education-82977 (26.05.2015)

[29] Milliyet, "Rusya'da Eğitim Gören ilk Türk Nükleer Mühendisleri Mezun Oluyor (The First Group of Turkish Nuclear Engineers Getting Education in Russia Are Graduating)".

http://www.milliyet.com.tr/egitim/rusyada-egitimgoren-ilk-turk-nukleer-muhendisleri-mezun-oluyor2570445 (17.12.2017). 